\title{
A Model for Full-Fledged Inflation Targeting and Application to Ghana
}

Ali Alichi, Kevin Clinton, Jihad Dagher,

Ondra Kamenik, Douglas Laxton, and

Marshall Mills 
IMF Working Paper

Research Department

\title{
A Model for Full-Fledged Inflation Targeting and Application to Ghana
}

\author{
Prepared by Ali Alichi, Kevin Clinton, Jihad Dagher, \\ Ondra Kamenik, Douglas Laxton, and Marshall Mills ${ }^{1}$
}

-DOXDI 2009

\begin{abstract}
This Working Paper should not be reported as representing the views of the IMF. The views expressed in this Working Paper are those of the authors and should not be attributed to the IMF, its Executive Board, or its management. Working Papers describe research in progress by the authors and are published to elicit comments and to further debate.

A model in which monetary policy pursues full-fledged inflation targeting adapts well to Ghana. Model features include: endogenous policy credibility; non-linearities in the inflation process; and a policy loss function that aims to minimize the variability of output and the interest rate, as well as deviations of inflation from the long-term low-inflation target. The optimal approach from initial high inflation to the ultimate target is gradual; and transitional inflation-reduction objectives are flexible. Over time, as policy earns credibility, expectations of inflation converge towards the long-run target, the output-inflation variability tradeoff improves, and optimal policy responses to shocks moderate.

JEL Classification Numbers: C51, E31, E52

Keywords:

Author’s E-Mail Address: aalichi@imf.org, kclinton@rogers.com,jdagher@imf.org, okamenik@imf.org,dlaxton@imf.org,mmills@imf.org

\footnotetext{
${ }^{1}$ The views expressed in this paper are those of the authors and should not be attributed to the IMF, its Executive Board, or its management. We thank Andy Berg, Charles Collyns, Arto Kovanen, Piroska Nagy, Peter Allum, and several participants at seminars at the Bank of Ghana and IMF for providing useful comments, and Laura Leon for her help with preparation of the paper. The contributions of participants from the Bank of Ghana in no way imply that this paper reflect their views. Special thanks go to Mohamed El Harrak, who contributed important data analysis. The code for the model simulations can be downloaded at www.douglaslaxton.org.
} 


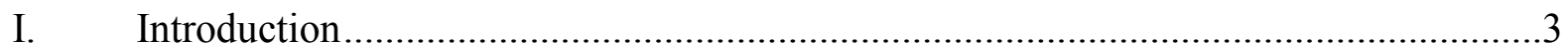

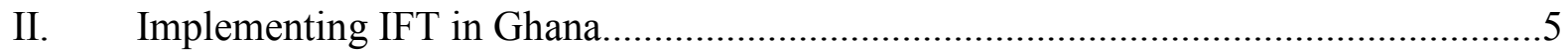

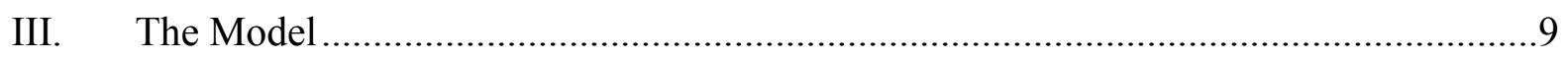

IV. Application of The Model to Ghana: Dynamic Responses to Shocks..........................11

A. Disinflation Under Imperfect and Full Credibility .............................................12

B. Demand and Supply Shocks Under Imperfect and Full Credibility ....................16

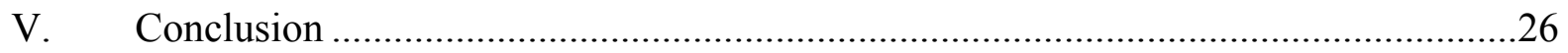

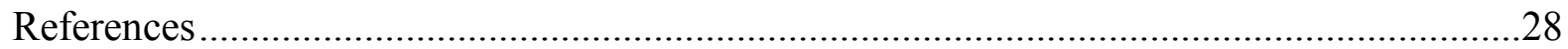

Figures

1. Ghana: CPI Inflation, Jan. 2000-June 2009 (year-on-year, percent) ............................4

2. Ghana: Linear versus Optimal Disinflation, 2009-2016

(year-on-year, percent) .................................................................................

3. Ghana: Baseline IT with Imperfect Credibility, 2009-2019 ……….........................14

4. Ghana: Baseline IT with Full Credibility, 2009-2019............................................16

5. Ghana: Positive Demand Shock with Imperfect Credibility, 2009-2019....................17

6. Ghana: Negative Demand Shock with Imperfect Credibiilty, 2009-2019 ..................18

7. Ghana: Positive Demand Shock with Full Credibility, 2009-2019.............................19

8. Ghana: Negative Demand Shock with Full Credibility, 2009-2019 …......................20

9. Ghana: Positive Supply Shock with Imperfect Credibility, 2009-2019 ......................21

10. Ghana: Negative Supply Shock with Imperfect Credibility, 2009-2019 .....................22

11. Ghana: Positive Supply Shock with Full Credibility, 2009-2019 ………..................23

12. Ghana: Negative Supply Shock with Full Credibility, 2009-2019 ............................24

13. Ghana: Baseline with Delayed Policy Response with Imperfect Credibility, 2009-2019 


\section{INTRODUCTION}

In May 2007, the Bank of Ghana formally adopted inflation targeting (IT), making it among the first emerging market economies and the first low income country to do so. The Bank of Ghana set a medium-term goal of 5 percent inflation within a band of +/- 1 percent, along with some intermediate inflation-reduction targets. Within a few months, however, global food and fuel price shocks pushed inflation up. And as these shocks began to unwind in 2008, expansionary fiscal policy created further inflationary pressures. As a result, headline inflation has diverged from the announced targets (Figure 1). Such problems, which are not uncommon in the inflation-reduction phase of IT, do not imply that the policy framework is unworkable, but they do reinforce the argument for flexible implementation of IT.

Over the past two decades, monetary authorities in numerous countries have announced numerical inflation-reduction targets, although success has been uneven. ${ }^{2}$ Most in the end achieved the goal they sought. But in the process, inflation outcomes were more often than not outside the target range. ${ }^{3}$ Difficulties are especially likely in economies that are more vulnerable to shocks, and that have a history of high and variable inflation, and may have weaker policy transmission mechanisms. Ghana, along with many emergingmarket countries, would be in this category.

In responding to shocks, the Bank of Ghana, like many other monetary authorities, has sought to reduce the variability of output and interest rates, rather than try to hit preannounced annual inflation targets at all cost. Given the structure of economy, and the nature of the shocks, a draconian IT policy would not have appropriately balanced output and inflation objectives. In several countries, monetary policy has reacted vigorously to short-run deviations from targets, in an attempt to maintain credibility. This had a destabilizing impact on the economy. Experience has shown that it is not desirable or even feasible to hit inflation targets every single year irrespective of the circumstances. The challenge is to maintain the credibility of the ultimate target, in the face of variations in the path of inflation.

\section{A flexible, forward-looking and transparent approach to IT - which Svensson (1997) described as inflation-forecast targeting (IFT) — can manage these types of difficulties. The objective of stabilizing output need not undermine the credibility of IFT. A central bank can strengthen its credibility by admitting that it does not just focus merely on annual}

\footnotetext{
${ }^{2}$ Examples of countries that have introduced inflation-reduction targets are Brazil, Canada, Chile, Colombia, Czech Republic, Hungary, Israel, Korea, Mexico, New Zealand, Peru, Poland, and the United Kingdom (Mishkin and Schmidt-Hebbel, 2001, Table 2).

${ }^{3}$ Roger and Stone (2005) found that the frequency of outcomes outside the range for countries with inflation targets was 60 percent, divided almost equally between overshoots and undershoots.
} 
inflation targets, and that it is mindful of short-run trade-offs against output and employment. IFT emphasizes the long-run commitment of monetary policy to low inflation, pursued through an optimal path which can change according to circumstances, rather than through fixed short run targets. As illustrated in Figure 1, a rigid approach of setting a series of shortterm targets is unlikely to be helpful, as they are not likely to be achieved in the face of shocks. The more flexible IFT approach is underpinned by a process of accountability and transparent communications. The central bank has to explain, on a regular basis, how its actions will help achieve the low-inflation goal. This, in turn, requires outlining a credible view of the transmission mechanism, from policy instruments to objectives. A macroeconomic model may be used both to inform decision making, and to provide clear, consistent explanations for policy actions.

Figure 1. Ghana: CPI Inflation, Jan 2000 - August 2009

(year-on-year, percent)

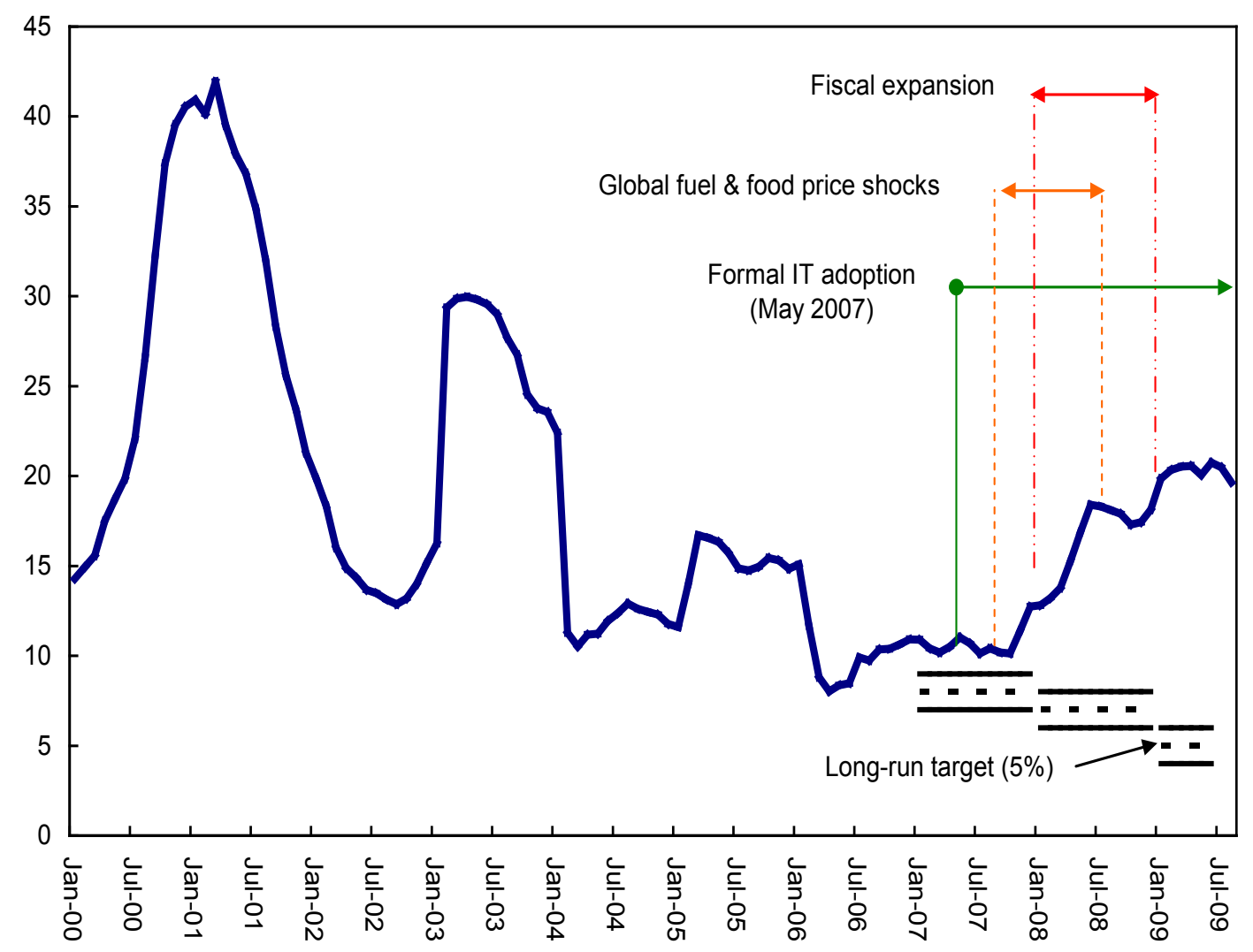

Successful inflation-forecast targeting itself alters behavior. The objective is to anchor expectations, such that price shocks have a quickly dampened effect on the inflation rate. There is considerable evidence that the widespread transition to lower inflation over the past 
twenty years has changed the process by which expectations are formed. ${ }^{4}$ Whereas, previously, expectations tended to drift with current and past inflation rates, transforming one-off shocks into prolonged inflation spirals, they have become anchored to the low inflation target. Thus, a model of disinflation for Ghana should incorporate an expectations process that allows the central bank to earn credibility, over time, as it makes progress to stable low inflation.

This paper argues that IFT can deal with the special difficulties that often confront disinflation policy in small, low-income economies. As the case in point, Ghana faces the following major challenges.

- It is highly vulnerable to supply shocks.

- Inflation expectations are likely unstable, given the past volatility of inflation.

- Inflation inertia is entrenched in wage setting.

- Rapid changes in the economy complicate modeling.

\section{IMPLEMENTING IFT IN GHANA}

Some basic questions face any central bank thinking of an inflation-reduction program:

- What is an appropriate pace of inflation reduction?

- How should monetary policy respond to unexpected events on the disinflation path?

- What sort of flexibility is appropriate in the execution of policy?

- What is the best way to explain policy to the public?

The model of Alichi and others (2009), which has endogenous policy credibility, and which allows an IFT regime, offers responses to these questions of relevance to Ghana.

\section{Uses of the model}

Models have become a standard tool in monetary policy decision making and communications. Policymakers have used models of the kind used in this paper to help assess the implications of different strategic options, and alternative responses to shocks.

\footnotetext{
${ }^{4}$ See, e.g., Laxton and N'Diaye (2002), Levin, Natalucci and Piger ( 2004), Goretti and Laxton (2005) and Mishkin (2007).
} 
These models are not mechanical guides to decision making, but tools to encourage consistent thinking based on standard economic theory.

\section{Some economists have worried that extensive empirical knowledge and advanced modeling capabilities were a prerequisite for IFT. ${ }^{5}$ The central banks that pioneered IT in the 1990s had large data bases, and a body of empirical work, to draw on. In a few cases macro modeling and forecasting capabilities were highly advanced. ${ }^{6}$ As more and more central banks adopted the approach, however, such concern has faded. A recent survey of central banks found that IT usually started without forecasting models that could be used by policymakers - see Batini, Kuttner and Laxton (2005) and Batini and Laxton (2007). Very few had models that could produce forecasts conditional on different assumptions for the monetary policy instrument, although IT often stimulated their development.}

\section{Technical developments in model building have made this task considerably easier for} an economy like Ghana's. The standard model for IT is small and focused, and accessible in broad outline to a wide audience. Modern practice is to calibrate the parameters, using a broad range of relevant empirical evidence. This is especially useful where classical econometric techniques are unlikely to yield reliable estimates, because of the scarcity of time-series data, and the frequency of structural breaks. ${ }^{7}$

\section{The model adopted in this paper should serve an iterative tool for monetary} policymaking. The analytical underpinnings of decision making are repeatedly tested against outcomes-leading, where necessary, to changes in the inflation forecasts targeted as the optimal response to various shocks and even potentially to re-calibration of the parameters based on structural transformation of the economy. The simpler reduced form of the model favors this adaptability. This flexibility for "learning by doing" is well adapted to the context like Ghana's, where ongoing structural change leads to evolving relationships among variables.

\footnotetext{
${ }^{5}$ For example, Eichengreen (1999).

${ }^{6}$ The Economist, 2006, traces the history of macro modeling in central banks. The Bank of Canada has used models for forecasting and policy analysis since the 1970s. The Reserve Bank of New Zealand (RBNZ) adopted a similar framework some years after it began IT (in 1989) — see Black and others (1994), Coletti and others (1996) and Hunt, Rose and Scott (2000). The development of the Forecasting and Policy Analysis Systems at the RBNZ, Norges Bank and Czech National Bank made it possible for them to adopt very high levels of operational transparency, including the publication of an endogenous path for the policy rate. However, the models used by many other central banks had an exogenous policy rate. This is not consistent with an IT regime, in which is the central bank must adjust the policy rate as required to keep inflation on target—-see Freedman and Laxton (2009a).

${ }^{7}$ Over time, as more data, and more sophisticated software has become available, Bayesian estimation methods have become more popular — see Berg, Karam, and Laxton, (2006a, b).
} 


\section{Communications and operational transparency}

\section{Perhaps the major challenge for an explicit program of inflation reduction in Ghana is to establish credibility. Communications are central to meeting this challenge. Since} inflation in Ghana has been high and variable for some time, people are prone to expect high rates to persist, unless they see an actual drop. They would give less weight to an announced policy of inflation reduction than to the actual rates they have recently witnessed. While usually high, inflation has varied significantly from year to year, so expectations are not stable. People are likely to interpret what should be a one-off shock as a lasting increase in inflation, setting off a self-feeding spiral. In contrast, in established low-inflation regimes, expectations are firmly anchored, and second-round effects of price shocks are typically negligible. Not surprisingly, deviations from targets have been larger during inflation reduction than under stable, low targets. ${ }^{8}$

Operational transparency is one key to gaining credibility for IFT, especially in an economy prone to shocks. Explaining to the public in detail how the Bank is pursuing its medium-term goal of low inflation minimizes the risk that short-term deviation might undermine credibility. A model can provide an explicit, consistent framework for the economic rationale of policy decisions. Central banks following inflation targets publish regular monetary policy reports that contain their forecast for inflation, ${ }^{9}$ and associated macroeconomic variables, with at least a qualitative indication of the likely course of the policy interest rate. Some have gone so far as to publish an explicit forecast for the policy interest rate. ${ }^{10}$

\section{The Bank of Ghana could strengthen the credibility of low inflation by disclosing} beforehand its strategy for managing various shocks. For example, it could explain ex ante why in the event of supply shocks, inflation would diverge from its target forecast path in the short term, and how the policy response would bring the inflation path back toward the medium-term goal. ${ }^{11}$ For example, Figure 2 shows simulated paths for an optimal response:

\footnotetext{
${ }^{8}$ For example, in Roger and Stone (2005), deviations from target range are twice as frequent for inflation reduction as for stable inflation targets.

${ }^{9}$ The Bank of Ghana has been publishing a CPI fan chart forecast in its inflation outlook and analysis report.

${ }^{10}$ They include: the Reserve Bank of New Zealand; the Norges Bank; the Riksbank; and the Czech National Bank. Lars Svensson and Michael Woodford have been prominent advocates of publishing the central banks forecast of the policy rate, e.g. Woodford (2005). Some recent evidence based on the Norges Bank experiences suggests that monetary policy has become more predictable in the sense that there are now smaller revisions in 1-year market rates following the release of the endogenous interest rate path in the Norges Bank Inflation Reports - see Freedman and Laxton (2009a, b, c).

${ }^{11}$ Freedman and Laxton (2009b) argue that imperfect policy credibility would imply a long horizon to communicate the logic of the relevant policy choices.
} 
first, with no shocks (the path is not linear); second, with a positive inflation shock; third; with a negative shock. The central bank could publish hypothetical paths of this kind to illustrate how the medium-term objective is maintained, despite the short-run divergence. ${ }^{12}$ While this approach may appear to rely on a sophisticated understanding by economic actors and the public, it has proven remarkably successful in anchoring expectations in a wide range of countries, including emerging market economies like Chile.

Figure 2. Ghana: Linear versus Optimal Disinflation, 2009-2016 ${ }^{1}$ (year-on-year, percent)

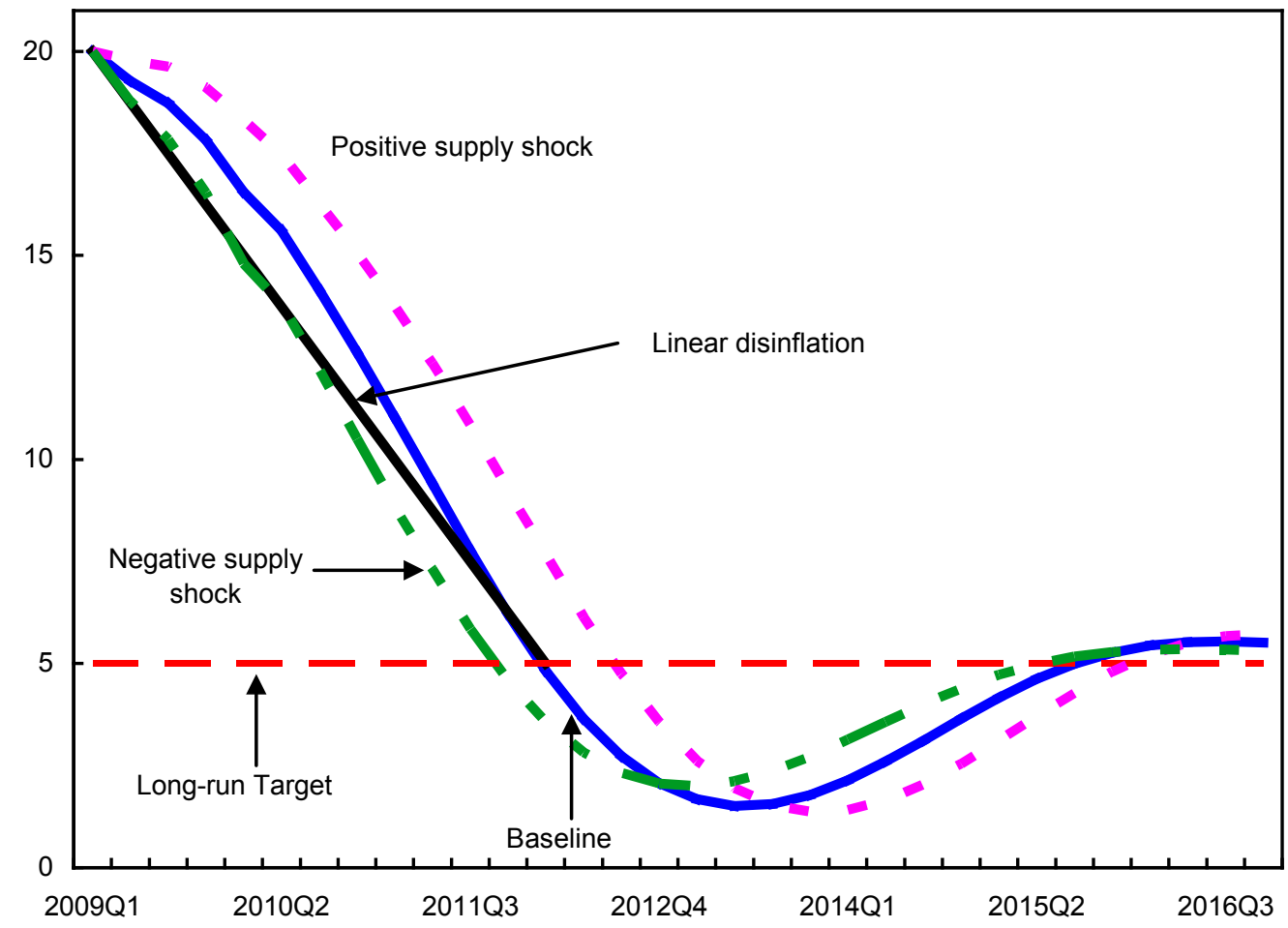

Source: IMF staff calculations.

${ }^{1}$ The optimal disinflation paths are as follows: Baseline (no shocks), Positive supply shock (a shock that leads to $2 \%$ increase in inflation), and Negative supply shock (a shock that leads to $2 \%$ decrease in inflation).

\footnotetext{
${ }^{12}$ Section III and IV discuss this issue further.
} 


\section{THE MODEL}

\section{Alichi and others (2009) adapt the work-horse model used at many central banks to} address the issue of implementing IFT in an emerging-market, low-income economy. ${ }^{13}$ The model has equations for:

- the output gap (actual minus potential output - a gauge of excess demand - as a function of the interest rate, the exchange rate, and external demand);

- the inflation rate (an expectations-augmented Phillips curve);

- the exchange rate (a relation embodying uncovered interest parity, a variable risk premium, and long-run purchasing power parity); and a

- monetary policy objective function (a loss function which weights deviations of inflation, output gaps, and interest rate variability - in place of a Taylor-type rule for the policy interest rate).

A wide range of international experience, from Ghana and elsewhere, influenced the model's development and calibration. Three features capture challenges of a policy of inflation reduction:

- an endogenous credibility process - credibility has to be earned: starting from a situation in which people expect inflation to remain high, policymakers may build credibility over time, such that public expectations of inflation converge on the target rate;

- a loss function for monetary policy which recognizes costs of fluctuations in output and interest rates, as well as costs of deviations of inflation from target - in place of a conventional reaction function for the policy interest rate;

- non-linearities in the specification for the output gap, and for the endogenous credibility process.

\section{Output gap equation}

The output gap equation relates the current gap to expected and past gaps, the real interest rate gap, the real exchange rate gap, and the foreign output gap:

$$
\operatorname{ygap}_{t}=\beta_{\text {ld }} \operatorname{ygap}_{t+1}+\beta_{\text {lag }} \operatorname{ygap}_{t-1}-\beta_{\text {RRgap }} \operatorname{RRgap}_{t-1}+\beta_{\text {zgap }} \text { zgap }_{t-1}+\beta_{\text {USygap }} y_{g a p_{t}^{U S}}+\varepsilon_{t}^{\text {ygap }},
$$

\footnotetext{
${ }^{13}$ Isard, Laxton and Eliasson (2001) introduced the endogenous credibility process into a standard New Keynesian model. Laxton and N'Diaye (2001), and Argov and others (2007) also use the idea.
} 
where $y g a p$ is the output gap, ygap $\max$ is the maximum output gap possible, RRgap is the real interest rate gap in percentage points, zgap is the real exchange rate (measured so an increase is a depreciation, in percentage points), and $y g a p^{U S}$ is the foreign output gap. The output gap is measured as the deviation, in percentage points, of actual output from a measure of the trend or equilibrium level of GDP (a positive number indicates that output is above trend). The inclusion of the future output gap as an explanatory variable reflects forward-looking behavior on the part of households and firms.

\section{Phillips curve}

The Phillips curve relates inflation to past and expected inflation, the output gap, and changes in the exchange rate: ${ }^{14}$

$$
\pi_{t}=\alpha_{\text {Idd }} \pi 4_{t}^{e}+\left(1-\alpha_{\text {Idd }}\right) \pi 4_{t-1}+\alpha_{\text {ygap }}\left[\operatorname{ygap}_{t-1} /\left(\operatorname{ygap}_{\max }-\operatorname{ygap}_{t-1}\right)\right] \operatorname{ygap}_{\max }+\alpha_{z}\left[z_{t}-z_{t-1}\right]+\varepsilon_{t}^{\pi},
$$

where $\pi$ is the annualized month-on-month inflation rate, $\pi 4$ is the four-quarter change in the CPI, $\pi 4_{t}^{e}$ is the forward looking component of inflation, which is formed based on past and future inflation, and $z$ is the real exchange rate.

\section{Exchange rate equation}

The exchange rate equation imposes uncovered interest parity (IP), the arbitrage condition that real interest rates (on investments in different currencies) will be equalized across countries, up to a country risk premium:

$$
z_{t}=\delta_{z} z_{t+1}+\left(1-\delta_{z}\right) z_{t-1}-\left[R R_{t}-R R_{t}^{U S}-\rho_{t}^{*}\right] / 4+\varepsilon_{t}^{z},
$$

where $R R^{U S}$ is the foreign real interest rate and $\rho *$ is the equilibrium risk premium. The first two terms on the right hand represent agents' real exchange rate expectations.

\section{Monetary policy loss function}

\section{Under IT, by definition, the monetary policy loss function attaches a high cost to deviations of inflation from target. In the model, the long-run low-inflation objective is primordial — the foundation of expectations and credibility.}

\footnotetext{
${ }^{14}$ The equation may also contain changes in international commodity prices-in particular for food and oil, to capture shocks to "non-core" inflation.
} 


\section{However, policymakers are also averse to fluctuations in output and variability of the} interest rate. Aiming to keep output at its potential level - i.e. minimizing the amplitude of the business cycle - has an obvious justification since this is a fundamental objective of macroeconomic policy. Aversion to interest rate variability, which is evident in the widely observed practice of central banks to adjust interest rates only gradually in response to changes in conditions, has a more technical rationale. Whereas the policy interest rate controlled by the central bank is a very short-term rate, the market interest rates that affect spending and output are not so short term. Effective transmission of policy actions requires that these market rates respond predictably, in line with movements in the policy rate. With low variability in the policy rate, financial markets can project that a change this quarter will have some duration in the quarters ahead. Longer-term rates, which incorporate expectations of the future policy rate, then respond relatively strongly to policy actions. ${ }^{15}$ High quarter-toquarter variability in the policy rate, on the other hand, reduces its impact on relevant market rates, and weakens the effectiveness of transmission.

\section{With these considerations in mind, the loss function in the model is a weighted sum of:}

- squared deviations from the inflation target

- $\quad$ squared output gaps, and

- $\quad$ squared one-quarter changes in the policy interest rate

$$
\text { Loss }=\sum_{i} \omega_{1}\left(\pi 4_{i}-\pi^{*}\right)^{2}+\omega_{2} y g a p_{i}^{2}+\omega_{3}\left(r s_{i}-r s_{i-1}\right)^{2}
$$

The weights $\left(\omega_{i}\right)$ represent the costs policymakers attach to each item.

Monetary policy minimizes the loss function, subject to the constraints imposed by the structure of the model. Policymakers have choices with respect to the path towards the inflation target. This may be fast, if the cost of misses is high relative to the costs of output and interest rate instability. Or it may be slow, if the cost of targeting errors is relatively low. The quadratic loss function implies symmetric aversion to overshoots and undershoots with respect to the inflation target. Despite the symmetric loss function, the full model need not imply policy symmetric responses to shocks of opposing directions. For example, endogenous credibility encourages a stronger interest rate response to inflationary than disinflationary shocks, especially when credibility is low and inflation is above the target.

\footnotetext{
${ }^{15}$ On these lines, Woodford (2003) argues that a strategy of gradual interest adjustment may be optimal.
} 


\section{Application Of The Model to Ghana: Dynamic Responses to Shocks}

We apply the model to a hypothetical IFT program in Ghana. In view of the recent history, the Bank of Ghana would need to produce ongoing declines in inflation to convince a skeptical public that it does intend to achieve the target it announces. ${ }^{16}$ In the model, given the long-run low-inflation target, the disinflation path is endogenous. The usual adjustment lags in spending and price setting imply rising costs of lost output, and increased interest rate variability, as the horizon for reaching the final target is shorter. In addition, monetary policy has to build credibility, which also takes time. The loss-minimizing path to the low-inflation goal is more gradual than it would be if policy were 100 percent credible at the outset.

The derived path of inflation reduction is smooth, but this requires a steep interest rate hike in the first four quarters of the program. Putting off the increase only means a larger increase later. We investigate below the implications of various initial conditions and shocks, and alternative policy options. Model simulations suggest that supply shocks can have an especially big impact on the desirable rate of disinflation. There are important asymmetries. A fortuitous supply shock, which reduces inflation, can help monetary policy, boosting credibility and reducing the necessary interest rate increase, and shortening the path to the long-run objective. A harmful supply shock-e.g. an increase in world energy or food prices - presents, in contrast, the most difficult problem for inflation control. Large interest rate increases may be needed to prevent a self-propagating inflation spiral. In such situations, delay in tightening money eventually results in even higher interest rates, and a more prolonged period with output below potential.

The variety of outcomes from differing starting points and different shocks reflects the forward-looking, flexible approach to IFT embedded in the model. Conventional reaction functions, in contrast, have fixed inflation targets, and adjust the policy interest rate on the basis of observed movements in target variables, regardless of the source of the shock. Flexibility, however, requires the central bank to show, on an ongoing basis, how it intends to reach the long-run, low-inflation objective. Actions - or delays - inconsistent with the objective carry a heavy cost in the model; they can result in medium-term stagflation.

\footnotetext{
${ }^{16}$ In the model, deviations from the long-run target weaken confidence, and so actual reductions in inflation are required to strengthen it. High real interest rates increase confidence only through their lagged effect on inflation. For financial markets, one could argue that a steep increase in interest rates could directly raise confidence, by signaling commitment. However, one has to think through the output/inflation trade-off carefully, including the negative effects of excessive increases and uncertainty about their sustainability.
} 


\section{A. Disinflation Under Imperfect and Full Credibility}

\section{Imperfect credibility case}

Credibility is imperfect in the sense that people do not have 100 percent confidence that the central bank will achieve its announced objectives - and may not even believe that the bank will try to achieve them. In forming their expectations, people give weight to the recent history of inflation, and to the risk that policymakers might not have a commitment to a low-inflation agenda. Monetary policy, however, has some credibility - for illustrative purposes, in the process of expectations formation, we set the initial weights at 0.5 on the announced low-inflation policy, and at 0.5 on the alternative possibility of a high-inflation policy. Furthermore, the central bank can earn an increased stock of credibility-moving the low-inflation weight towards unity_-by steering inflation towards the official long-term objective.

Monetary policy in the model follows a loss-minimizing strategy to get to the long-run inflation target of 5 percent. We posit initial conditions similar to those prevailing in Ghana in the 2009:Q1. The economy is overheating: inflation is high; excess demand (partly because of the fiscal position) is providing further inflationary stimulus. In numerical terms, to start the model simulations, we set the 2009:Q1 rate of inflation at 20 percent, the output gap (excess demand) at 1.6 percent; and the short-term rate of interest controlled by the central bank at 18.5 percent. The initial real interest rate is less than zero-and hence significantly smaller than the neutral rate. The central bank implements a loss-minimizing IFT approach to the long-run target.

Given the level of inflation expectations at the outset and the lags in the expectations process, the central bank has to raise the policy rate substantially to engineer the required increase in the real interest rate. The panels in Figure 3 show the simulated baseline scenario. Optimal policy in the model involves raising the interest rate to 26.2 percent in 2009:Q2, and to a peak of 27 percent in 2009:Q4.

This has an immediate impact on the nominal price of foreign exchange: the US dollar drops percent against the domestic currency. The higher domestic inflation rate versus the United States implies that the real exchange rate value of the cedi rises by more than the nominal rate, i.e. by around 24 percent. The increased interest rate and real appreciation of the currency reduce demand for domestic output. This eliminates excess demand; and a large negative output gap begins to develop - by 2013 the implied cumulative loss of output is equivalent to 20 percent of one year's GDP. This represents the output sacrifice required for disinflation in the model. 
Figure 3. Ghana: Baseline IT with Imperfect Credibility, 2009-2019 ${ }^{1}$
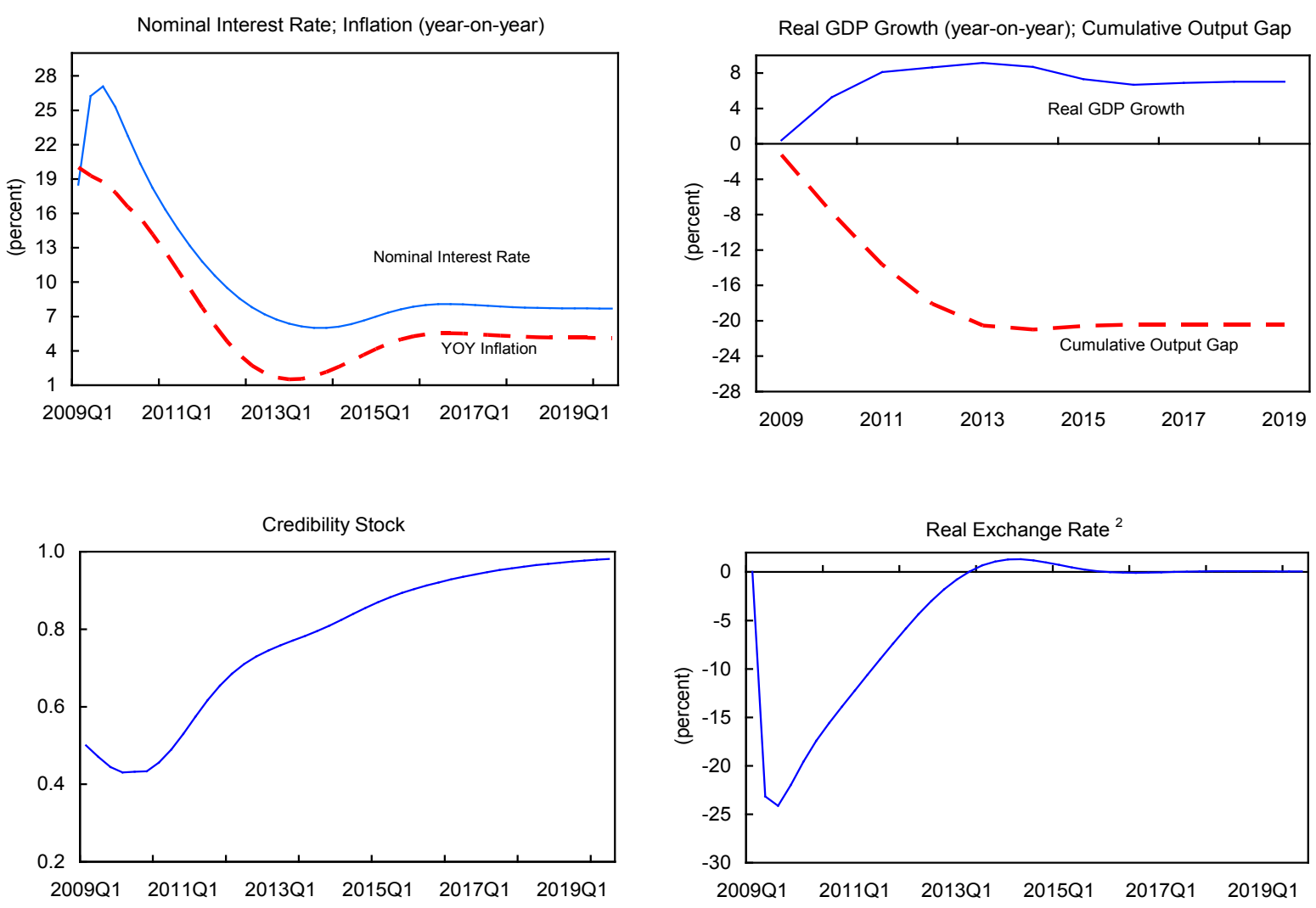

Source: IMF staff calculations.

${ }^{1}$ All variables are quarterly, except for Real GDP growth, which is annual because quarterly GDP data are not reported in Ghana.

${ }^{2}$ Increase represents depreciation of the cedi.

Excess productive capacity, over time, reduces the rate of inflation. The simulation even shows some undershooting on the way to the 5 percent target. The public gradually revises downwards its expectations of inflation, and gives increased weight to the announced 5 percent target. Monetary policy eventually reduces the inflation rate by 15 percentage points over a 3-year horizon. The implied sacrifice ratio (the cumulative output loss divided by the inflation reduction) of 1.33 would be, by historical standards, a fairly typical estimate for a major disinflation. ${ }^{17}$

Low credibility results in upward-biased expectations. During the inflation-reduction phase people expect a rate higher than monetary policy actually delivers. Since expectations

${ }^{17}$ For example, the decline is more rapid than the announced inflation reduction targets in Table 9, Roger and Stone (2005). In some countries, however, especially the Czech Republic, actual inflation fell much more quickly than the target - see Coats, Laxton and Rose (2003). 
have a direct effect on actual inflation in the Phillips curve, monetary policy has to be tighter than if people had 100 percent confidence in the objectives, and the loss of output is greater. In particular, high inflation expectations can also create inflation inertia, as workers demand wage increases in line with past inflation. Institutional reforms such as forward-looking wage indexation can address this rigidity. Thus, low credibility worsens the short-run inflationoutput trade-off.

By 2016, the economy is almost on its full long-run equilibrium path. The stock of credibility is close to unity, and the output gap is virtually zero. The real exchange stabilizes at its initial equilibrium value, but the nominal exchange rate continues to rise, reflecting the domestic-US inflation differential.

\section{Full credibility case}

To highlight the effect of the credibility problem, this sub-section describes a path of inflation reduction under the assumption that the public has full confidence from the outset in the target announced by the Bank of Ghana. Thus, in the expectations process, the weight is one on the public's perception of the possibility that the central bank is in fact committed to the low-inflation objective, and zero on the possibility the bank is not committed to the low-inflation goal. The assumption of 100 percent credibility implies that this simulation yields the fastest path of disinflation consistent with loss minimization. In other words, the simulated path in this experiment describes an upper limit to the desirable pace of disinflation reduction.

\section{The results show inflation declining to the 5 percent range within a couple of years} (Figure 4). This is achieved via the strong announcement effect when credibility is 100 percent. The reduction in expected inflation itself raises the real interest rate above the natural rate, without an increase in the nominal rate. Indeed, the nominal rate declines through the disinflation phase, as the inflation premium goes down. The sacrifice ratio is almost negligible. 
Figure 4. Ghana: Baseline IT with Full Credibility, 2009-2019 ${ }^{1}$
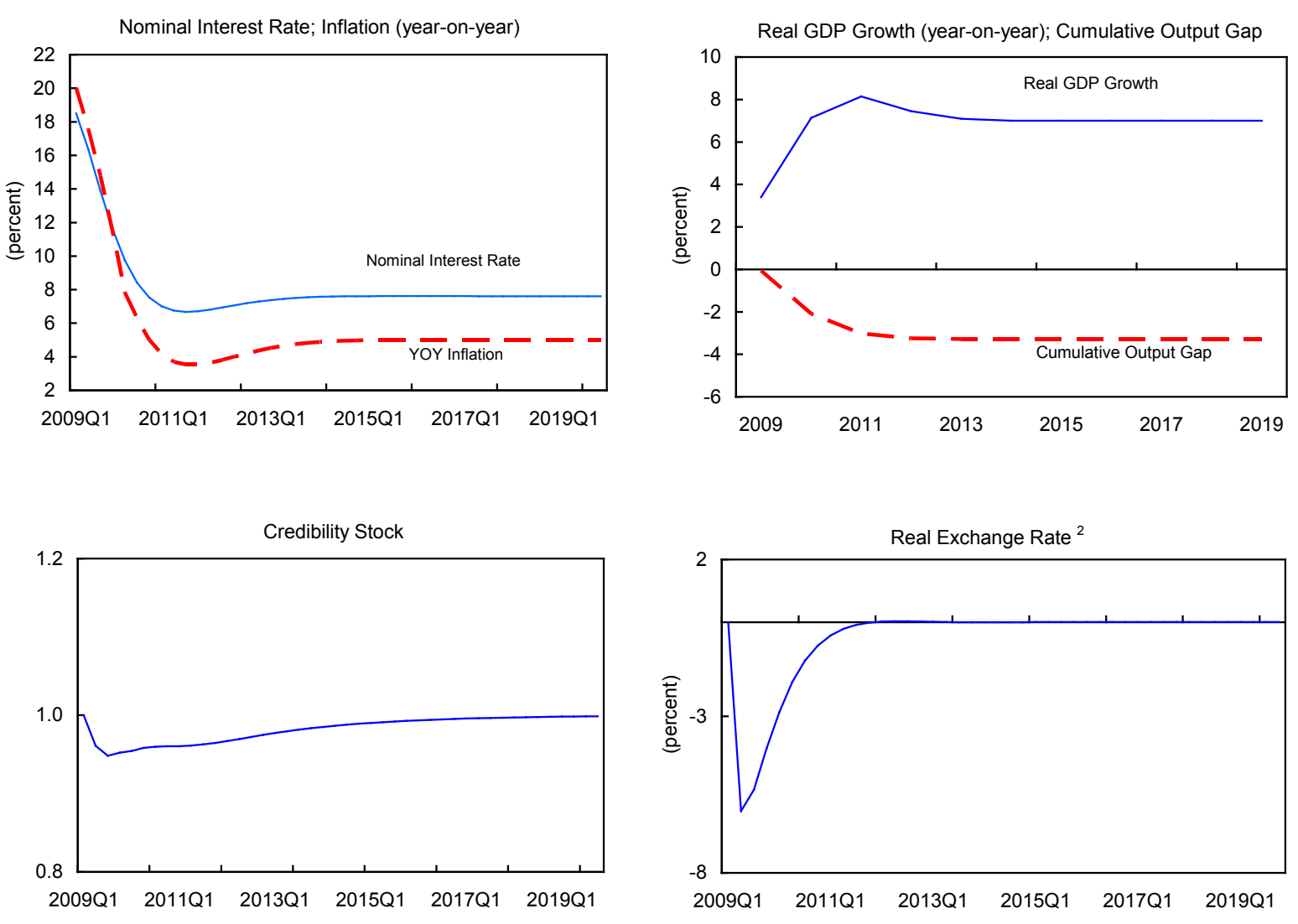

Source: IMF staff calculations.

${ }^{1}$ All variables are quarterly, except for Real GDP growth, which is annual because quarterly GDP data are not reported in Ghana.

${ }^{2}$ Increase represents depreciation of the cedi.

\section{B. Demand and Supply Shocks Under Imperfect and Full Credibility}

The simulated shocks —one expansionary, the other contractionary—represent one-off exogenous changes in domestic demand in 2009:Q2, i.e. an increase or decrease in aggregate demand equivalent to 2 percent of GDP.

\section{Demand shock under imperfect credibility}

For the expansionary shock, the model indicates that the appropriate policy action would be to raise the interest rate quite sharply relative to the baseline simulation (Figure 5). Thus, the interest rate would be 10 percentage points above baseline in the second and third quarter of 2009. In levels, this would mean a peak policy rate of 37 percent, in 2009:Q3. In response to this increased tightening, the real exchange rate appreciates a 
further 15 percentage points relative to baseline, or 39 percent from its 2009:Q1 level. It then starts returning to its original level (the "overshooting" implied by uncovered interest parity). The robust policy action, which accepts high real interest rates, as well as a sharp appreciation of the cedi, achieves its purpose: the output gap is eliminated within a year; inflation is held close to target; and the stock of policy credibility is maintained. More generally, for an expansionary demand shock in this model, the appropriate policy reaction involves a prompt change in the interest rate (and hence in the exchange rate), which effectively mitigates the impact on the goal variables.

Figure 5. Ghana: Positive Demand Shock with Imperfect Credibility, 2009-20191

Dotted $=$ Positive Demand Shock ${ }^{2}$; Solid $=$ Baseline
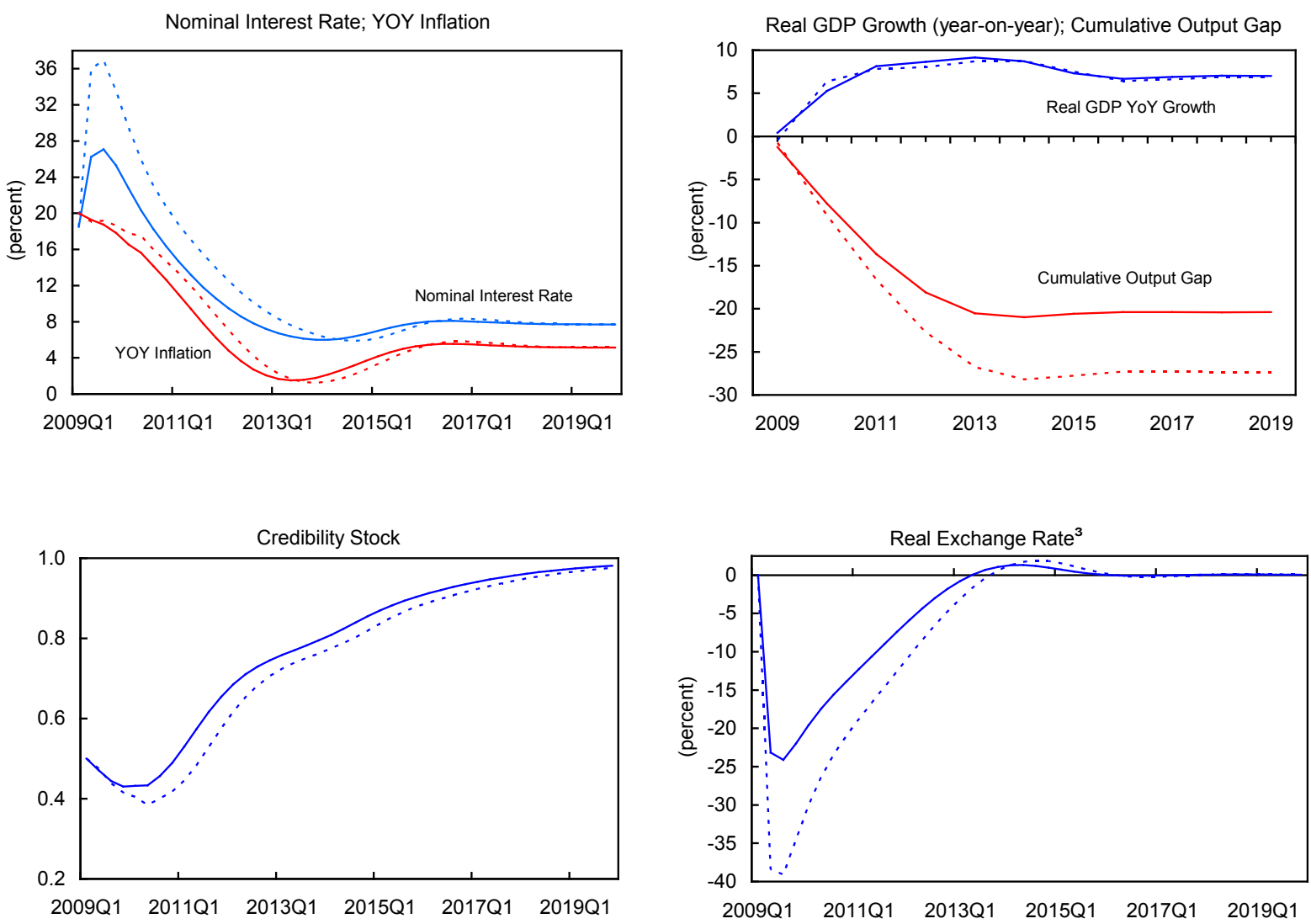

Source: Staff calculations.

${ }^{1}$ All variables are quarterly, except for Real GDP growth, which is annual because quarterly GDP data are not reported in Ghana.

${ }^{2} \mathrm{~A}$ shock that leads to an increase of excess demand by $2 \%$ of GDP.

${ }^{3} \mathrm{An}$ increase represents depreciation of cedi. 
The contractionary shock requires a significantly smaller policy reaction (Figure 6). The interest rate at its peak is slightly below 21 percent-i.e., 6 percentage points below the peak under the baseline scenario. Inflation hardly differs from baseline.

\section{One reason for the asymmetry in the size of the optimal monetary policy reaction to} expansionary and contractionary supply shocks is that in the case of the first, unlike the second, the Bank of Ghana has to offset the potential weakening of credibility. In effect, the drop in demand in the second experiment does some of the work for monetary policy. These optimal responses hold regardless of the origin of the demand shock. ${ }^{18}$

Figure 6. Ghana: Negative Demand Shock with Imperfect Credibility, 2009-20191 Dotted $=$ Negative Demand Shock ${ }^{2}$; Solid $=$ Baseline
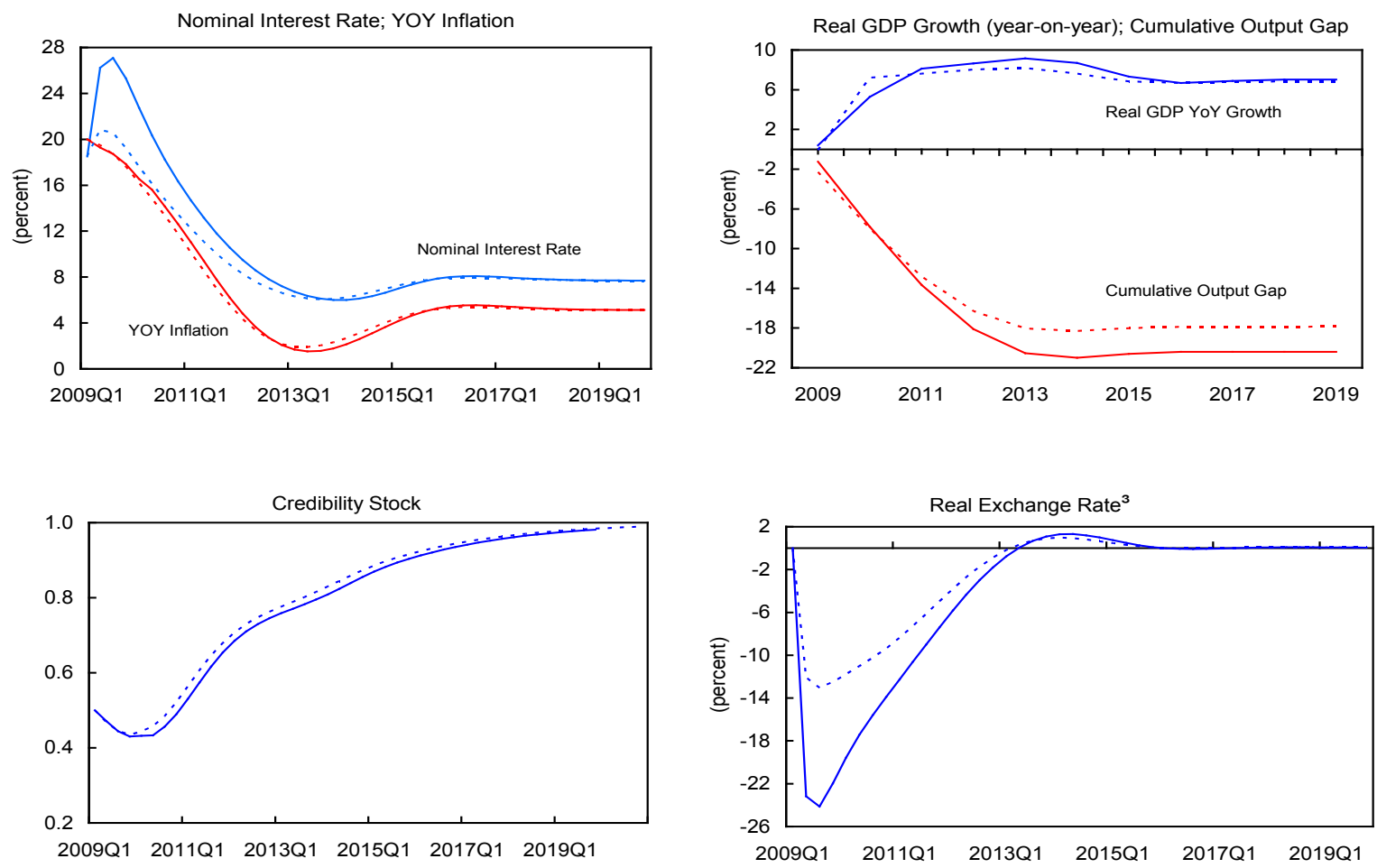

Source: Staff calculations.

${ }^{1}$ All variables are quarterly, except for Real GDP growth, which is annual because quarterly GDP data are not reported in Ghana.

${ }^{2}$ A shock that leads to a decrease of excess demand by $2 \%$ of GDP.

${ }^{3}$ An increase represents depreciation of cedi.

\footnotetext{
${ }^{18}$ In recent years fiscal stimulus in Ghana has been a major source of expansionary demand shocks. The actual fiscal deficit has differed significantly from the planned budget and rose from 3 percent of GDP in 2005 to 7.5 percent in 2006 to 9.2 percent in 2007 to 14.5 percent in 2008 . The government plans a fiscal adjustment, of around 5 percent in 2009. The model results for a contractionary demand shock indicate that this would greatly facilitate disinflation.
} 


\section{Demand shock under full credibility}

In the long run monetary policy keeps inflation at the target rate, with output at potential, and policy becomes 100 percent credible. The establishment of full credibility moderates the optimal policy reaction to shocks, as it becomes easier to meet the inflation target.

This is illustrated in Figure 7, which shows the effects of the 2 percent expansionary shock, starting in 2009:2, under full credibility. Loss minimization requires that the Bank of Ghana raise the interest rate, relative to baseline, by at most 6 percentage points. The real price of foreign exchange briefly drops about 10 percent below baseline. The contractionary shock (Figure 8) elicits a somewhat smaller optimal policy action.

Figure 7. Ghana: Positive Demand Shock with Full Credibility, 2009-20191

Dotted $=$ Positive Demand Shock ${ }^{2} ;$ Solid $=$ Baseline
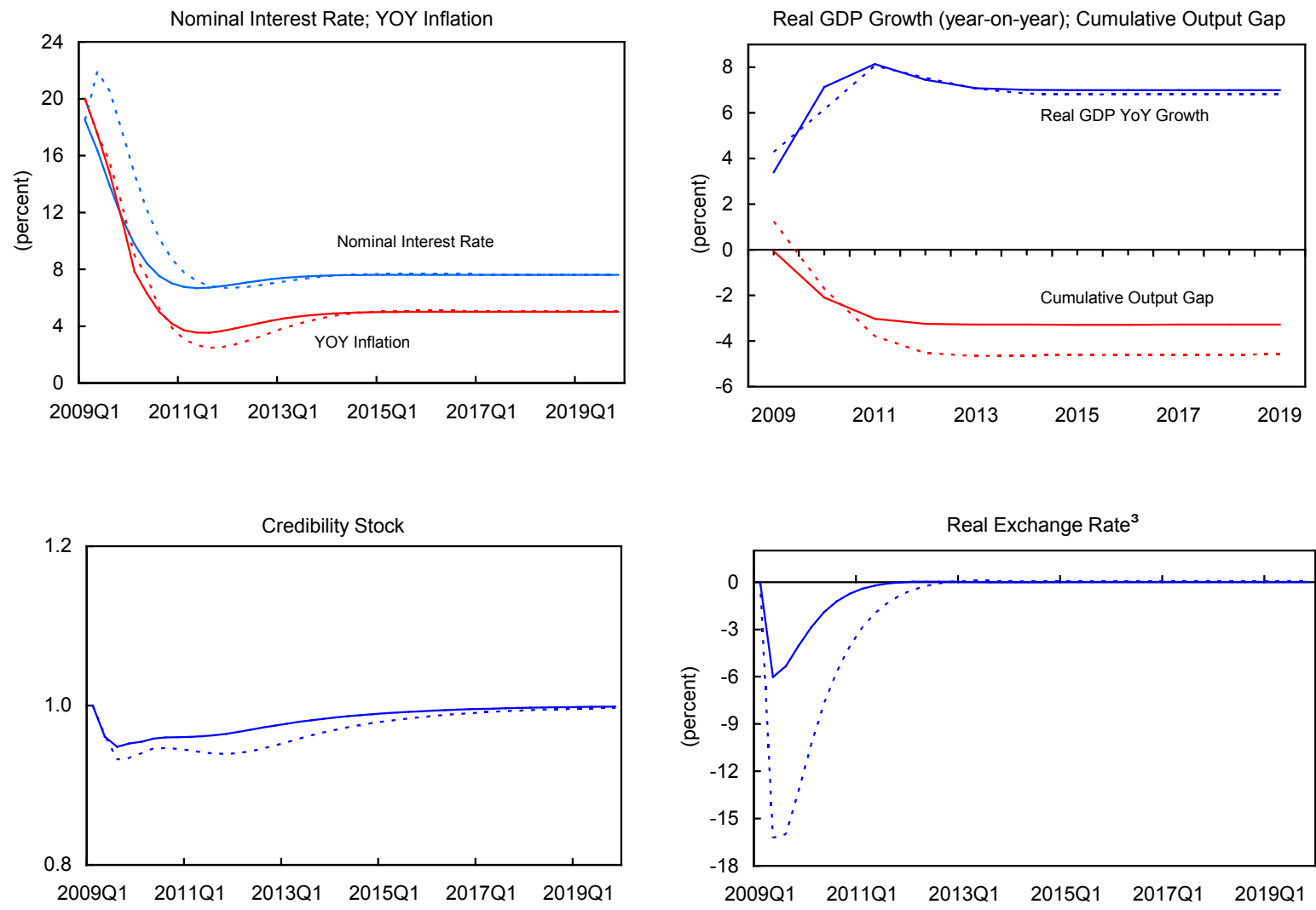

Source: Staff calculations.

${ }^{1}$ All variables are quarterly, except for Real GDP growth, which is annual because quarterly GDP data are not reported in Ghana.

${ }^{2}$ A shock that leads to an increase of excess demand by $2 \%$ of GDP.

${ }^{3} \mathrm{An}$ increase represents depreciation of cedi. 
Figure 8. Ghana: Negative Demand Shock with Full Credibility, 2009-20191 Dotted $=$ Negative Demand Shock ${ }^{2} ;$ Solid $=$ Baseline
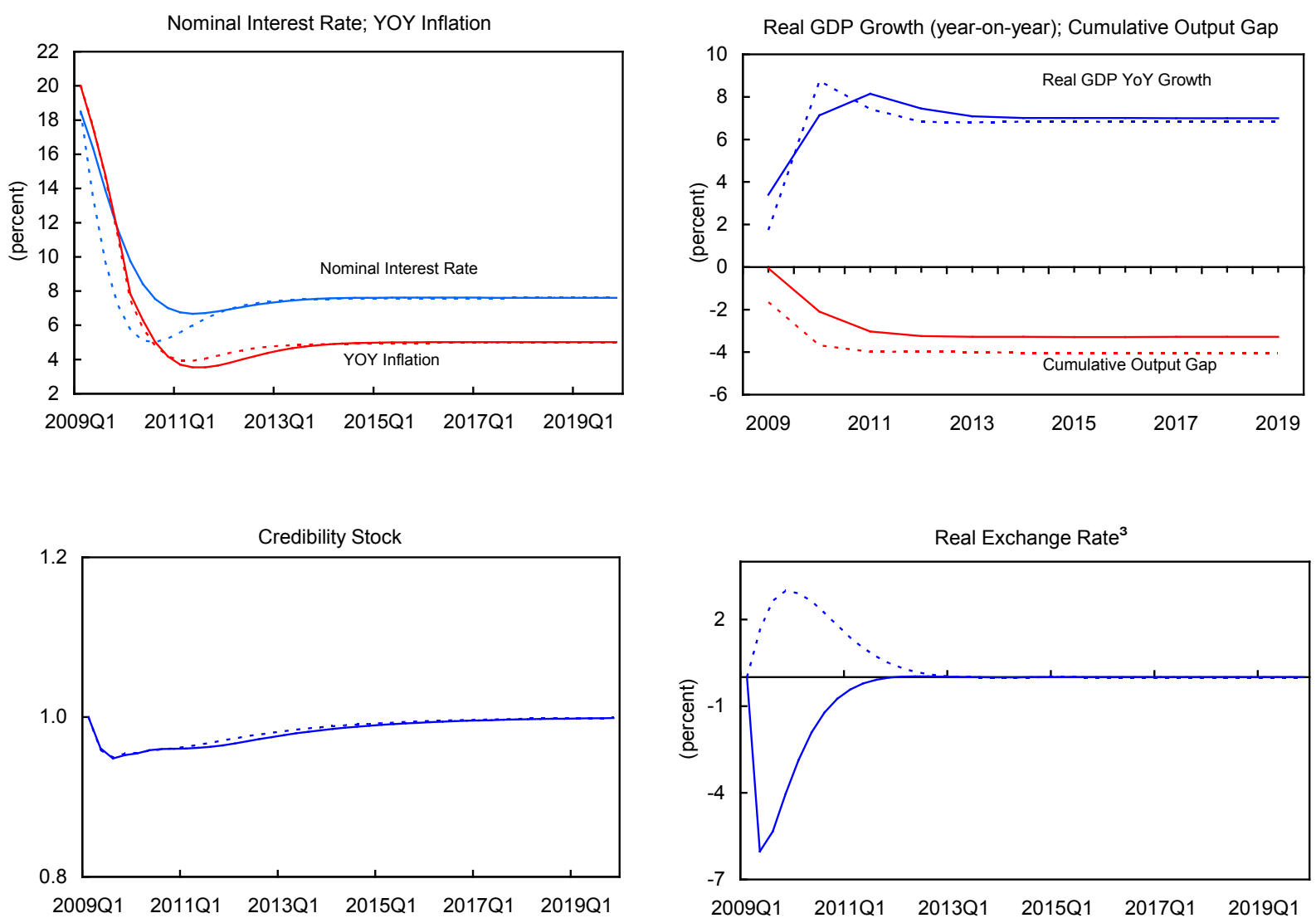

Source: Staff calculations.

${ }^{1}$ All variables are quarterly, except for Real GDP growth, which is annual because quarterly GDP data are not reported in Ghana.

${ }^{2}$ A shock that leads to a decrease of excess demand by $2 \%$ of GDP.

${ }^{3}$ An increase represents depreciation of cedi.

\section{Supply shock under imperfect credibility}

Supply shocks pose very difficult challenges for a disinflation program. The first experiment here is a one-off, two-percent, in the rate of inflation in 2009:Q2-e.g., an increase in world energy and food prices. Policy has to guard against an inflationary spiral, as the short-run increase in inflation causes people to expect higher inflation in the future, and to lose confidence in the 5 percent objective. 
Figure 9. Ghana: Positive Supply Shock with Imperfect Credibility, 2009-20191

Dotted $=$ Positive supply shock ${ }^{2} ;$ Solid $=$ Baseline
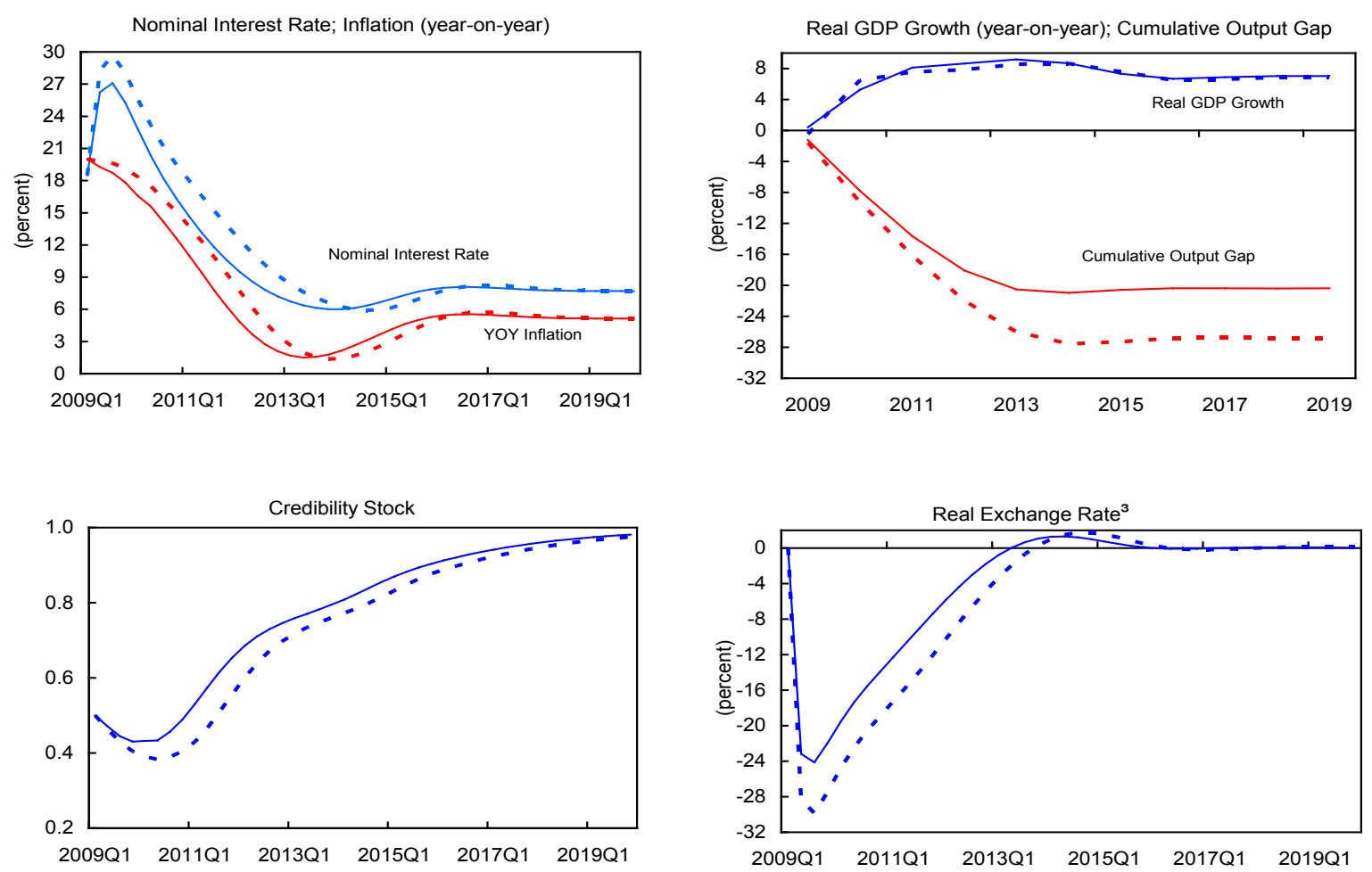

Source: IMF staff calculations.

${ }^{1}$ All variables are quarterly, except for Real GDP growth, which is annual because quarterly GDP data are not reported in Ghana.

${ }^{2} \mathrm{~A}$ shock that leads to $2 \%$ increase in inflation.

${ }^{3}$ An increase represents depreciation of cedi.

\section{The loss-minimizing policy calls for a substantial and lasting increase in the interest} rate relative to the baseline (Figure 9). In levels, the interest rate peaks at 29.7 percent in 2009:Q3. This reaction — and the large, albeit short-lived, appreciation of the exchange rate that accompanies it - does not prevent a prolonged divergence of inflation from target. Twelve quarters after the shock, inflation is still about 2 percentage points above the baseline rate. The reasons for this divergence are:

- the lagged response of the output gap responds to the interest rate and exchange rate

- the adverse and self-reinforcing impact of the increase in inflation on expectations and credibility

The potential size and duration of the effects of adverse supply shocks on inflation, even with appropriate resistance from monetary policy, is a major reason for avoiding rigid adherence to short-run targets. 
The second experiment, a supply shock reducing inflation, presents less difficulty

(Figure 10). The inflation rate does fall below the baseline for an extended period, but this is in line with the announced policy objective, and boosts the stock of credibility. In effect, with the fortuitous assistance of this supply shock, the Bank of Ghana does not have to raise the interest rate to the same level as in the baseline case.

Figure 10. Ghana: Negative Supply Shock with Imperfect Credibility, 2009-20191 Dotted $=$ Negative supply shock ${ }^{2}$; Solid $=$ Baseline
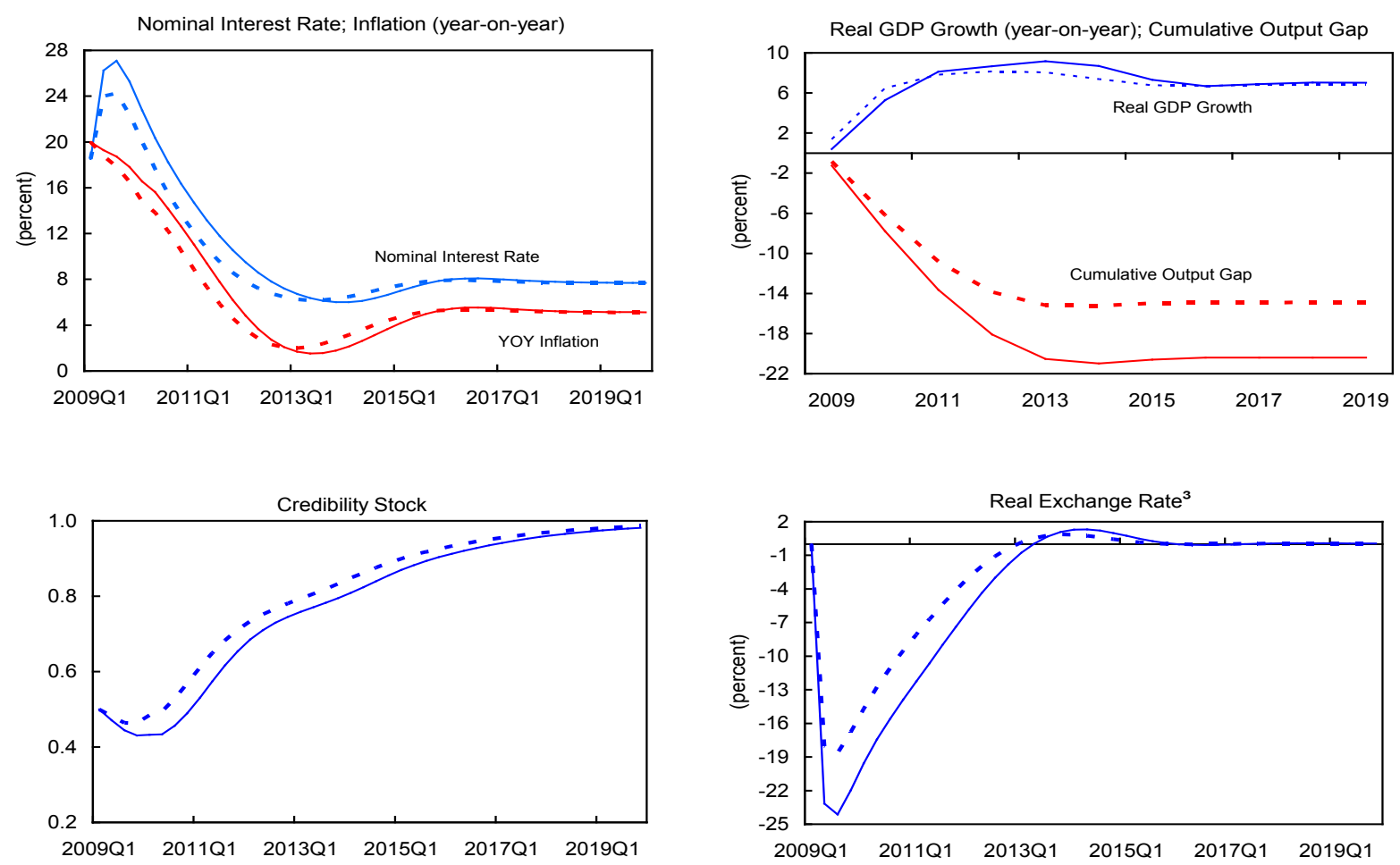

Source: IMF staff calculations.

${ }^{1}$ All variables are quarterly, except for Real GDP growth, which is annual because quarterly GDP data are not reported in Ghana.

${ }^{2} \mathrm{~A}$ shock that leads to a $2 \%$ decrease in inflation.

${ }^{3}$ An increase represents depreciation of cedi.

\section{Supply shock under full credibility}

The quantitative impact of imperfect credibility is clear from the contrasting results from a simulation of the inflationary supply shock under the assumption of full credibility. In this case, the Bank of Ghana's optimal policy response - the increase in the policy rate relative to the baseline - is barely visible (Figure 11). The real price of foreign exchange shows a small, brief increase. These changes are sufficient to keep inflation close to the baseline path, because public expectations of inflation are strongly anchored. 
Figure 11. Ghana: Positive Supply Shock with Full Credibility, 2009-20191

Dotted $=$ Positive supply shock ${ }^{2} ;$ Solid $=$ Baseline
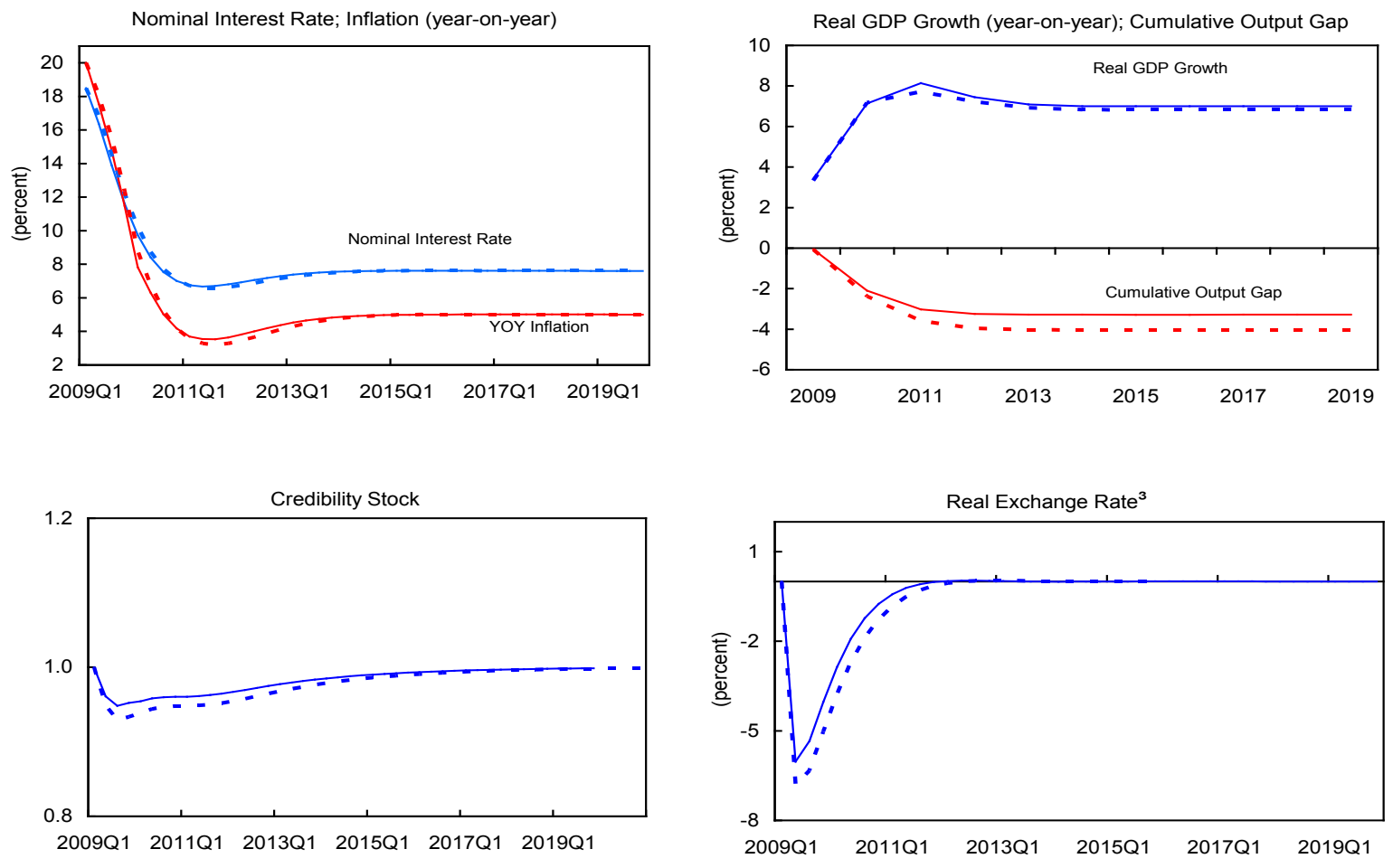

Source: IMF staff calculations.

${ }^{1}$ All variables are quarterly, except for Real GDP growth, which is annual because quarterly GDP data are not reported in Ghana.

${ }^{2}$ A shock that leads to $2 \%$ increase in inflation

${ }^{3}$ An increase represents depreciation of cedi.

This result is in line with the experience of the past two decades in countries that have moved from high to stable, low inflation. In the 1970s and 80s, unstable expectations transformed what should have been small price-level shocks - e.g. energy price increases and currency depreciations - into inflation spirals. Monetary policy contained the problem in the end, but only with very tight monetary policy, and at the cost of a substantial output loss. Since the early 1990s, however, many central banks have re-established a low-inflation environment and monetary policy credibility. The public in these economies now has confidence that the low-inflation policy objective will prevail, even after substantial shocks to the price level. This virtually eliminates a second round of price increases.

\section{A beneficial supply shock under conditions of full monetary policy credibility has} almost symmetric implications to the adverse shock (Figure 12). The differences (or asymmetries) between the effects of positive and negative shocks during the process of credibility-building are no longer present. These contrasts between imperfect and full credibility situations repeatedly illustrate Woodford's dictum (2005): "For not only do 
expectations about monetary policy matter, but at least under current conditions, very little else matters".

Figure 12. Ghana: Negative Supply Shock with Full Credibility, 2009-20191 Dotted $=$ Negative supply shock ${ }^{2} ;$ Solid $=$ Baseline
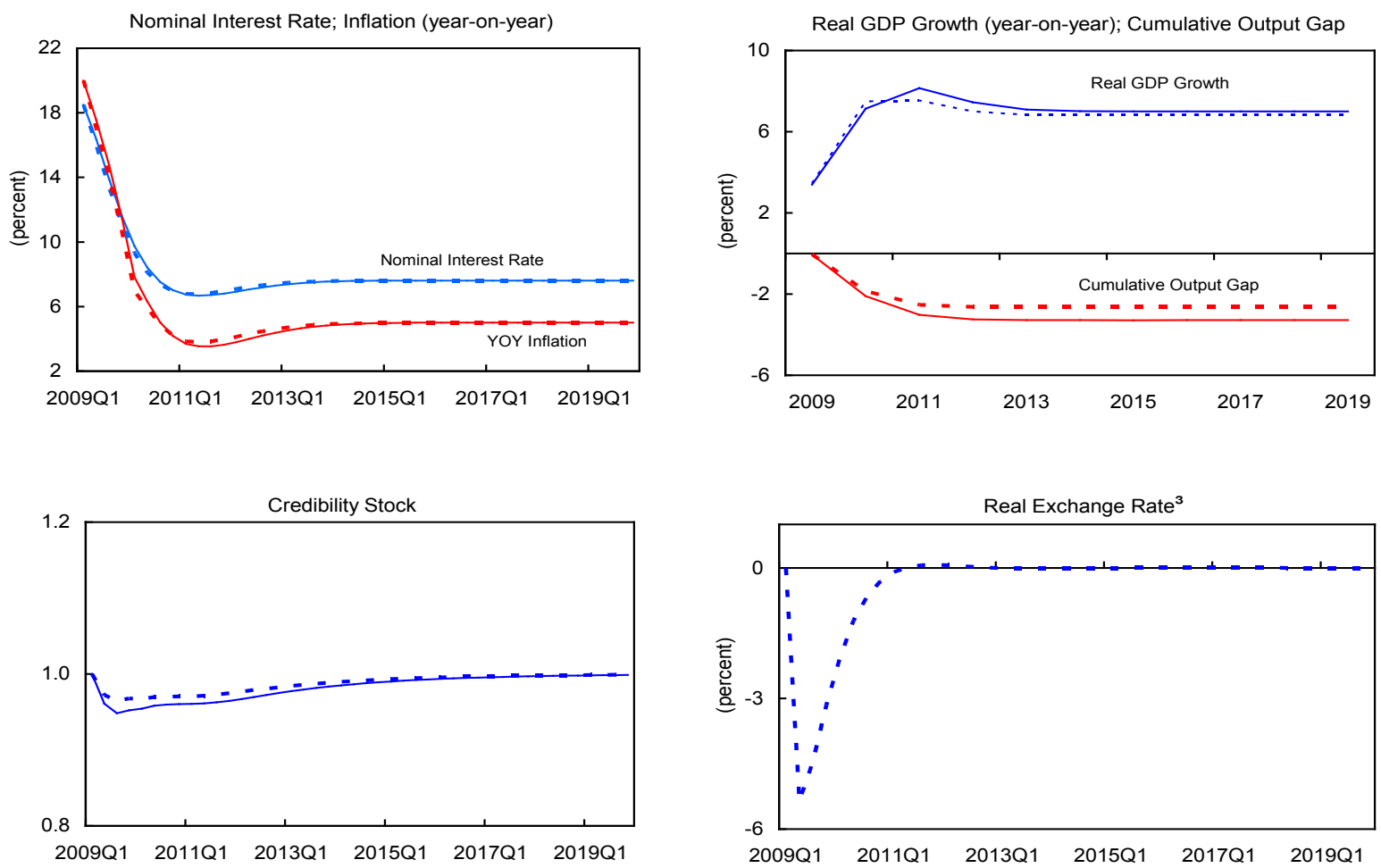

Source: IMF staff calculations.

${ }^{1}$ All variables are quarterly, except for Real GDP growth, which is annual because quarterly GDP data are not reported in Ghana.

${ }^{2} \mathrm{~A}$ shock that leads to a $2 \%$ decrease in inflation.

${ }^{3}$ An increase represents depreciation of cedi.

\section{Costs of delaying interest rate increase under imperfect credibility}

\section{The importance of credibility is further illustrated by the sharply higher costs of} delaying a rate increase under imperfect credibility. Suppose policymakers put off the required large interest rate increases for 4 quarters, until 2010:Q1, out of concern to maintain the level of output. The simulated response shows serious inflationary consequences (Figure 13). For several years the deviation between this scenario's inflation rate and the baseline rate widens - to over 14 percent in 2012. The inflation rate would remain well above baseline, and in double digits until 2014. Following the initial hesitation, the interest rate has to play catch-up and eventually rise to much higher levels than baseline - to around 30 percent in 2010. From a historical perspective, this would not be unprecedented-e.g., in the early 1980s the Federal Reserve and the Bank of Canada had to raise short-term interest 
rates above 20 percent to stop double-digit inflation. In the face of inflation, a short-run, low interest rate policy can turn into a long-run, high interest rate policy.

Figure 13. Ghana: Baseline with Delayed Policy Response with Imperfect Credibility, 2009-2019¹ Dotted $=$ Delayed response $;$ Solid $=$ Baseline
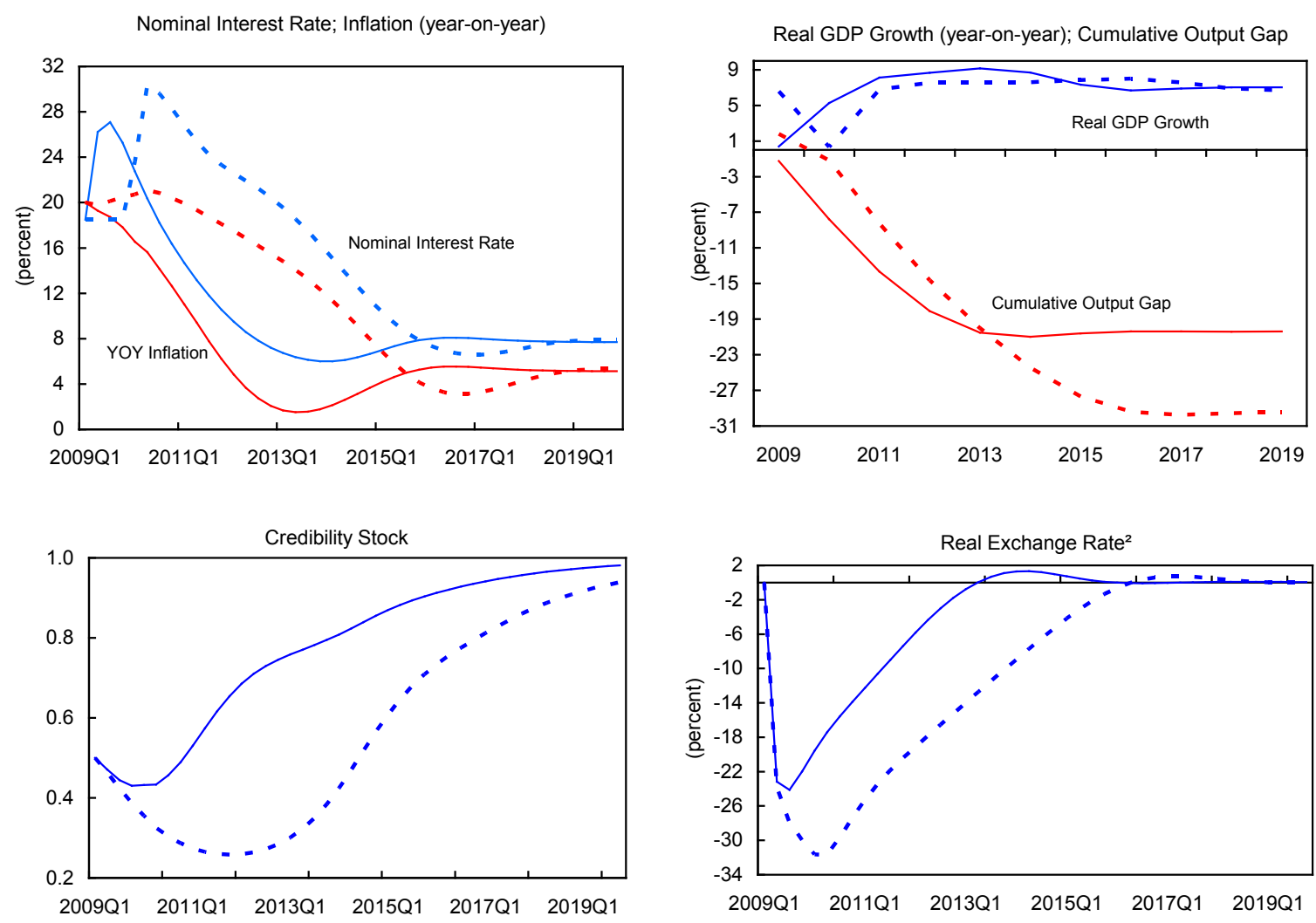

\footnotetext{
Source: IMF staff calculations.

${ }^{1}$ All variables are quarterly, except for Real GDP growth, which is annual because quarterly GDP data are not reported in Ghana.

${ }^{2}$ An increase represents depreciation of cedi.
}

An erosion of credibility is, not surprisingly, a large part of the problem. Credibility declines as the inflation rate fails to decline, the simulated stock of credibility falling from 0.5 to almost 0.2 (i.e. a decline of 60 percent) by 2012:Q1.

The delay in raising the interest rate does keep demand high in the short run-indeed, excess demand intensifies for several quarters. But disinflation requires that a negative output gap eventually open up, and the cumulative gap is eventually much wider than in the baseline. Thus, the cost of the monetary policy delay is several years of stagflation. 


\section{Conclusion}

Monetary policy in Ghana, as in many other emerging-market economies, faces various difficulties in implementing a program of inflation reduction. At the outset, people tend to expect that recent rates of inflation will continue in the future. The credibility of announcements of inflation-reduction is, therefore, low. The economy is vulnerable to external shocks, and undergoing rapid structural change. Policymakers may be hesitant to raise interest rates by enough to get the economy onto a disinflation track at the expense of a sharp contraction in output.

IFT, in principle, offers a response to these challenges. A wide body of evidence indicates that consistent pursuit of low inflation eventually earns itself credibility. Flexible short-run inflation targets allow the central bank to moderate movements in interest rates and output. As long as the path to the long-run goal of low inflation is transparent, the central bank has a considerable degree of freedom in its short-run actions. To this end, the bank would explain in advance its likely reaction to several kinds of shock, and how this would affect short-run targets.

Applying our model to Ghana illustrates how it is well adapted to addressing these difficulties. Its endogenous credibility process allows monetary policy to earn (or lose) credibility, as inflation declines towards the long-run target (or rises away from it). The policy loss function recognizes policymakers' aversion to output gaps, and to variability in the interest rate. Given the initial conditions, and the long-run target, one may derive a sequence of short-run inflation-reduction targets, which are flexible in that they respond to disturbances. A loss-minimizing monetary policy would not be locked to a rigid path of inflation reduction. But at each stage, the model provides an explicit path to the long-run, low-inflation objective.

Model simulations bear out some rather intuitive lessons. They suggest a way for Ghana, and economies with similar characteristics, to achieve stable, low inflation, over time. The optimal path is more rapid, and involves less short-run loss of output, the greater is its credibility. A central bank must, however, be prepared to raise interest rates to a level that dampens demand and brings about visible reductions in inflation. Delaying the policy response - e.g., out of an excessive concern for maintaining short-run output-weakens credibility and results in larger, more prolonged output losses.

The results suggest that normal demand shocks can be addressed relatively easily, because the monetary instrument itself acts through demand channels. However, the fiscal/monetary policy mix still matters. Persistent expansionary budgets constitute on ongoing demand shock, which forces the central bank to raise interest rates above the level otherwise required. The scenario with a negative demand shock illustrates that budget restraint, as envisaged under Ghana's current plans, can facilitate the achievement of low 
inflation. Indeed, successful IT regimes in emerging markets have usually involved a supportive fiscal policy. ${ }^{19}$ This issue will require increasing attention as Ghana becomes an oil exporter, with large foreign revenues, and increased fiscal exposure to world oil price fluctuations.

\section{Adverse supply shocks, such as those experienced by Ghana soon after adopting} inflation targeting, pose a serious challenge for monetary policy. Because of the asymmetric impact on credibility, policy should respond more vigorously to inflationary than to disinflationary impulses. A favorable supply shock helps achieve disinflation, with smaller interest rate increases and output losses than would otherwise be necessary. But the effects of an adverse supply shock on inflation can be large and long-lasting, even with an appropriate policy response, particularly when credibility is low, because of the impact on inflation expectations.

\footnotetext{
${ }^{19}$ Notable examples include Chile, Israel and Turkey.
} 


\section{REFERENCES}

Alichi, A., H. Chen, K. Clinton, C. Freedman, M. Johnson, O. Kamenik, T. Kisinbay, D. Laxton, 2009, "Inflation Targeting Under Imperfect Policy Credibility," IMF Working Paper 09/94.

Alichi, A., D. Laxton, M. Mills, P.M. Nagy, A. Shanghavi, H. Weisfeld, 2008, "Inflation Targeting in a Low Income Country: The Case of Ghana”, IMF Selected Issues Paper (June), available at www.imf.org.

Argov, E., N. Epstein, P. Karam, D. Laxton, and D. Rose, 2007, "Endogenous Monetary Policy Credibility in a Small Structural Model of Israel," IMF Working Paper 07/207 (August 2007), available at www.imf.org.

Batini, N., K. Kuttner, and D. Laxton, 2005, "Does Inflation Targeting Work in Emerging Markets?" Chapter 4 of the September 2005, World Economic Outlook, International Monetary Fund, available at www.imf.org.

Batini, N., and D. Laxton, 2007, "Under What Conditions Can Inflation Targeting Be Adopted? The Experience of Emerging Markets," in Monetary Policy under Inflation Targeting, ed. by Frederick S. Mishkin and Klaus Schmidt-Hebbel (Chile: Banco Central de Chile), pp. 467-506.

Barro, R.J., and D.B Gordon,1983, "Rules, Discretion and Reputation in a Model of Monetary Policy,” Journal of Monetary Economics, Vol 12, 1, pp. 101-21.

Berg, A., P. Karam, and D. Laxton, 2006a, "A Practical Model-Based Approach to Monetary Policy Analysis-Overview,” IMF Working Paper WP/06/80.

—_, 2006b, "Practical Model-Based Monetary Policy Analysis_A How-to Guide," IMF Working Paper WP/06/81.

Black, R., D. Laxton, D. Rose, and R. Tetlow, 1994, “The Steady-State Model: SSQPM,” The Bank of Canada's New Quarterly Projection System, Part 1, Bank of Canada Technical Report No. 72.

Coats, W., D. Laxton, and D. Rose, editors, 2003, The Czech National Bank's Forecasting and Policy Analysis System, Prague, (Czech Republic: Czech National Bank). 
Coletti, D., Hunt, B., D. Rose, and R. Tetlow, 1996, "The Dynamic Model: QPM,” The Bank of Canada's New Quarterly Projection System, Part 3, Bank of Canada Technical Report No. 75.

Eichengreen, B., P. Masson, M. Savastano and S. Sharma,, 1999, "Transition Strategies and Nominal Anchors on the Road to Greater Exchange-Rate Flexibility," Essays in International Finance, Vol. 213, Princeton.

The Economist, 2006, "Big Questions and Big Numbers-Economic Models," Special Report, (July), pp. 67-69.

Freedman, C., and D. Laxton, 2009a, "Why Inflation Targeting" IMF Working Paper WP/09/86; and Chapter 2, "Implementing Full-Fledged Inflation Targeting Regimes: Saying What You Do and Doing What You Say," unpublished manuscript by C. Freedman, D. Laxton, and I. Ötker-Robe, IMF.

Freedman, C., and D. Laxton, 2009b, "IT Framework Design Parameters," IMF Working Paper WP/09/87. Chapter 3, "Implementing Full-Fledged Inflation Targeting Regimes: Saying What You Do and Doing What You Say," unpublished manuscript by, C. Freedman, D. Laxton, and I. Ötker-Robe, IMF.

Freedman, C., and D. Laxton, 2009c, "Inflation Targeting Pillars: Transparency, Communications and Accountability," forthcoming IMF Working Paper and Chapter 4, "Implementing Full-Fledged Inflation Targeting Regimes: Saying What You Do and Doing What You Say," unpublished manuscript by C. Freedman, D. Laxton, and I. Ötker-Robe, IMF.

Goretti, M., and D. Laxton, 2005, "Long-Term Inflation Expectations and Credibility," Box 4.2 in Chapter 4 of the September 2005, World Economic Outlook, International Monetary Fund, available at www.imf.org.

Hunt, B., D. Rose, and A. Scott, 2000, "The Core Model of the Reserve Bank of New Zealand's Forecasting and Policy System," Economic Modeling, Vol. 17 (April) pp. 247-74.

Isard, P., D. Laxton, and A. Eliasson, 2001, "Inflation Targeting with NAIRU Uncertainty and Endogenous Policy Credibility, Journal of Economic Dynamics \& Control, Vol. 25, pp. 115-48. 
Laxton, D., and P. N'Diaye, 2002. "Monetary Policy Credibility and the UnemploymentInflation Trade-Off: Some Evidence from 17 Industrial Countries," IMF Working Paper 02/220.

Laxton, D., D. Rose, and D. Tambakis, 1999, "The U.S. Phillips Curve The Case for Asymmetry," Journal of Economic Dynamics and Control, Vol. 23, No. 9, pp. $1459-85$.

Levin, A. T., F. M. Natalucci, and J. M. Piger, 2004, "The Macroeconomic Effects of Inflation Targeting," The Federal Reserve Bank of St. Louis Review, July/August, pp. 51-80.

Mishkin F., 2007, "Inflation Dynamics," Annual Macro Conference, Federal Reserve Bank of San Francisco, (March), http://www.federalreserve.gov/news events/speech/mishkin20070323a.htm

Mishkin, F., and K. Schmidt-Hebbel, 2001, "One Decade of Inflation Targeting in the World: What Do We Know and What Do We Need to Know?" Central Bank of Chile Working Papers No. 101.

Roger, S. and M. Stone, 2005, "On Target? The International Experience with Achieving Inflation Targets," IMF Working Paper WP/05/163.

Svensson, L.E.O., 2000, “Open-Economy Inflation Targeting,” Journal of International Economics, Vol. 50, pp. 155-83.

Michael Woodford, 2003, “Optimal Monetary Policy Inertia,” Review of Economic Studies, Vol. 70, pp. 861-86.

— 2005. "Central Bank Communication and Policy Effectiveness," Federal Reserve Bank of St Louis, Jackson Hole Symposium, The Greenspan Era: Lessons for the Future (September). 